\title{
Canine Placenta Recellularized Using Yolk Sac Cells with Vascular Endothelial Growth Factor
}

\author{
Paula Fratini, ${ }^{1, \dagger}$ Nathia Nathaly Rigoglio, ${ }^{1, \dagger}$ Gustavo de Sá Schiavo Matias, ${ }^{1, \dagger}$ Ana Claudia O. Carreira, ${ }^{1-3}$ \\ Rose Eli Grassi Rici, ${ }^{1}$ and Maria Angelica Miglino ${ }^{1, *}$
}

\begin{abstract}
Regenerative medicine has been growing because of the emergent need for tissues/organs for transplants and restorative surgeries. Biological scaffolds are important tools to try to solve this problem. The one used in this reserach was developed by an acellular biological scaffold from canine placenta with a rich source of cellular matrix. After decellularization, the cellular matrix demonstrated structural preservation with the presence of important functional proteins such as collagen, fibronectin, and laminin. We used cells transduced with vascular endothelial growth factor (VEGF) to recellularize this scaffold. It was succeeded by seeding the cells in nonadherent plaques in the presence of the sterelized placenta scaffold. Cells were adhered to the scaffold when analyzed by immunocytochemistry and scanning electron microscopy, both showing sprouting of yolk sac VEGF (YSVEGF) cells. This recellularized scaffold is a promissory biomaterial for repairing injured areas where neovascularization is required.
\end{abstract}

Keywords: extracellular matrix; decellularization; recellularization; placenta; yolk sac cells; VEGF

\section{Introduction}

The necessity of tissues and organs for transplants exceeds its availability, taking to search for therapeutic alternatives.

A new tool as biological scaffolds derived from decellularized tissues and organs, more specifically extracellular matrix (ECM) may be useful in human and animal regenerative medicine as an alternative to transplantation. These scaffolds have been successfully applied in preclinical and clinical trials. ${ }^{1}$

The ECMs may originate from various tissues such as heart, ${ }^{2,3}$ blood vessels, ${ }^{4,5}$ skin, ${ }^{6}$ tendons, ${ }^{7}$ kidney, ${ }^{8}$ lung, ${ }^{9,10}$ and others. In order for this matrix to be considered functional, several molecules should be preserved in its structure, include collagens, glycos- aminoglycans, proteoglycans, growth factors, and adhesion proteins such as laminin and fibronectin. ${ }^{11}$ These molecules are essential for the interaction between cell/scaffold and structural maintenance of matrix. $^{12}$

Among various organs and tissues that can be used in regenerative medicine, there is the placenta, discarded at birth. Due to its rich parenchyma, the placenta has been used in the production of biological biomaterials. ${ }^{13-15}$

The different morphological placental types can be well applied to tissue engineering. In the case of the canine species, the endothelialchorial placenta is formed by maternal endothelium, interstitial lamina, trophoblast, basal lamina, and fetal endothelium. ${ }^{16}$ This type

${ }^{1}$ Department of Surgery, Faculty of Veterinary Medicine and Animal Science, University of São Paulo, São Paulo, Brazil.

${ }^{2}$ NUCEL (Cell and Molecular Therapy Center) and NETCEM (Center for Studies in Cell and Molecular Therapy), Medical Clinics Department, School of Medicine, University of São Paulo, São Paulo, Brazil.

${ }^{3}$ Department of Biotechnology, Interunits Graduate Program in Biotechnology, Institute of Biosciences, University of São Paulo, São Paulo, Brazil.

${ }^{\dagger}$ These authors contributed equally to this work.

*Address correspondence to: Maria Angelica Miglino, PhD, Department of Surgery, Faculty of Veterinary Medicine and Animal Science, University of São Paulo, São Paulo 05508-270, Brazil, E-mail: miglino@usp.br

(c) Paula Fratini et al. 2018; Published by Mary Ann Liebert, Inc. This Open Access article is distributed under the terms of the Creative Commons License (http://creativecommons.org/licenses/by/4.0), which permits unrestricted use, distribution, and reproduction in any medium, provided the original work is properly cited. 
of placenta is found in carnivores, such as the dog, ${ }^{17}$ cat, ${ }^{18,19}$ and others. ${ }^{20,21}$ This placental type is characterized by the uterine epithelium. The endotheliochorial type occurs in parts of all four major subtypes of mammals, including carnivores. ${ }^{16}$

Placenta as biological scaffolds, independent of the species, are promising for use as decellularized as well as recellularized, due to their rich protein complexity in ECM and developed vasculature. ${ }^{22}$ The placental differences between species such as morphology, size, and ECM composition should be considered in possible applications in tissue bioengineering. ${ }^{23,24}$ Studies use the decellularized human placenta as a biomaterial for the healing wound models, ${ }^{13,25}$ repair cartilage degradation, ${ }^{26}$ liver injury, ${ }^{27}$ treatment of contact hypersensitivity, ${ }^{28}$ and repair of wound in periarticular tissue $^{14}$ and extract of human placental matrix and growth factors as a hydrogel that effectively supports cardiomyocytes in vitro. ${ }^{29}$ Recently, the bovine placenta decellularization with possibilities of recellularization due to the vasculature preservation was characterized. ${ }^{15}$

Thus, the placental ECM may constitute a possible acellular bioactive biomaterial to be associated with stem cells for applications in tissue bioengineering.

Canine yolk sac cells transduced with VEGFeGFP (YSVEGF) previously characterized by our group ${ }^{30}$ were used to recellularize the canine placenta scaffold. These cells have endothelial progenitor characteristics and capacity to form sproutings in functional assays. This makes it an important tool for the production of scaffolds for use in regenerative medicine where tissue neovascularization is necessary.

\section{Materials and Methods}

\section{Canine placenta decellularization}

Placentas of female dogs with 35 days were collected from castration campaigns. The placentas were separated into maternal and fetal portions and left in $0.1 \%$ sterile sodium dodecyl sulfate (SDS) for 15 days under agitation, in a sterile environment. After, they were washed in $1 \%$ Triton X-100. Ethics Committee number 6611181016.

\section{DNA quantification}

The genomic DNA was isolated from $30 \mathrm{mg}$ of the decellularized canine placenta using the Illustra Kit (GE Healthcare). Samples were digested with Proteinase $\mathrm{K}$ and lysis buffer at $56^{\circ} \mathrm{C}$ for $2 \mathrm{~h}$. They were an- alyzed in a spectrophotometer at $260 \mathrm{~nm}$ (Nanodrop; Thermo).

\section{Critical point and sterilization}

The placentas were passed through the critical point LEICA EM CPD 300 after decellularization. At the final, the scaffolds were completely dry.

\section{Recellularization process}

The critical-point decellularized placentas were washed in $1 \times$ phosphate buffered saline (PBS) with $0.5 \%$ antibiotic (penicillin-streptomycin) and left in ultraviolet (UV) light for $10 \mathrm{~min}$. They were tested on alpha minimum essential medium (MEM) culture medium with $10 \%$ of fetal bovine serum and incubated at $37^{\circ} \mathrm{C}$ with $5 \% \mathrm{CO}_{2}$ for $24 \mathrm{~h}$. An amount of $5 \times 10^{4}$ YSVEGF and YS (control) cells, previously described by our group, ${ }^{30}$ were plated on untreated plates (Sarstedt) inside the scaffolds for 7 days.

\section{Immunocytochemistry}

The plates containing the YS/YSVEGF cells and scaffolds were fixed with $4 \%$ paraformaldehyde. The scaffolds were washed with PBS $+0.5 \%$ Tween and incubated with the primary antibody fibronectin (Abcam) at 1:200 dilution. Then, they were washed in PBS $+0.5 \%$ Tween and the secondary antibody Alexafluor 594 (Thermo Fisher). Plates were incubated with DAPI for nuclear labeling. They were analyzed on the Confocal Microscope-Olympus Fluo View 1000 (FV1000).

\section{Scanning electron microscopy}

The decellularized and recellularized placentas were fixed in $4 \%$ paraformoldehyde. They were dehydrated in increasing concentrations of alcohol, dried in a critical point, and glued with carbon tape in metallic (sputtercoating) with golden metallizer. They were photographed in a scanning electron microscope (SEM) LEO 435VP.

\section{Results and Discussion}

We developed an acellular biological scaffold derived from canine placenta preserving its architecture. The presence of important proteins in your constitution (collagen, laminin, and fibronectin) ${ }^{31}$ contributed of being recellularized with YSVEGF cells. The genomic DNA analysis showed complete scaffold decellularization using SDS and Triton ${ }^{11}$ (Supplementary Fig. S1). For the recellularization assay, we carry out 
sterilization of the scaffold, passed at critical point (Supplementary Fig. S2).

The alteration of the YSVEGF cell morphology was observed in the presence of scaffold in culture when compared to YS control cell (Fig. 1). The YSVEGF cells formed sproutings and rearranged into cord-like colonies, reminding the formation of endothelial cells. The immunocytochemical analysis confirmed the presence of adhered YSVEGF cells in the canine placenta as well as the YS cells and showed enhanced expression of fibronectin in the scaffold recellularized with YSVEGF, proving the efficacy of the method (Fig. 2). By SEM, we observed the presence of cellular colonies between scaffold fibers (Supplementary Fig. S3). Thus, proving that YS cells are a source effective for recellularization of biological scaffolds.

We observed that YSVEGF forming sproutings, a fact already demonstrated in another study of our group. $^{30}$ This fact reinforces the idea that these cells would have the promising potential of forming a neovascularized tissue when appropriate factors and conditions are provided.

Vascular endothelial growth factor (VEGF), which is also present in YSVEGF cells, is the main regulator of angiogenesis, whose mechanism is better understood as sprouting, which is able to aid in neovascularization in the formation of new vessels. ${ }^{32}$
In the immunocytochemical assay, we observed overexpression of fibronectin in the scaffold that received the YSVEGF cells. According to the literature, the interaction of VEGF with ECM influences cell differentiation, modulation, and migration of cells and factors that may influence its expression. ${ }^{32}$ In studies where VEGF gene therapy for recovery of infarcted cardiac areas was performed, fibronectin expression increased due to cell proliferation. ${ }^{33}$

YS cells (YSCs) from dogs are shown to be a promising source of progenitor cells. As seen in other in vitro studies, they expressed Oct 3/4 (pluripotency) and cadherin protein for vascular endothelium (VE-cadherin) and when injected into immunosuppressed mice, they did not develop teratomas. ${ }^{34}$

YSC was also described for rodents, the immunophenotyping confirmed the mesenchymal nature of these cells $\left(\mathrm{CD}_{3} 3^{+}, \mathrm{CD} 90^{+}\right.$and $\left.\mathrm{CD} 105^{+}\right)$as well as pluripotency markers (Oct3/4 and Nanog), vascular growth (VEGF), and hematopoietic cell precursors (CD117). ${ }^{20}$ The functions of these structures are related to the important role that the YS have to the development of the vascular system of the embryo. ${ }^{35}$

There are many strategies adopted for the recellularization of biological scaffolds. Among them we can mention the use of bioreactors ${ }^{36-38}$ and spinners flasks ${ }^{39,40}$ or the immersion/agitation in detergent solutions.
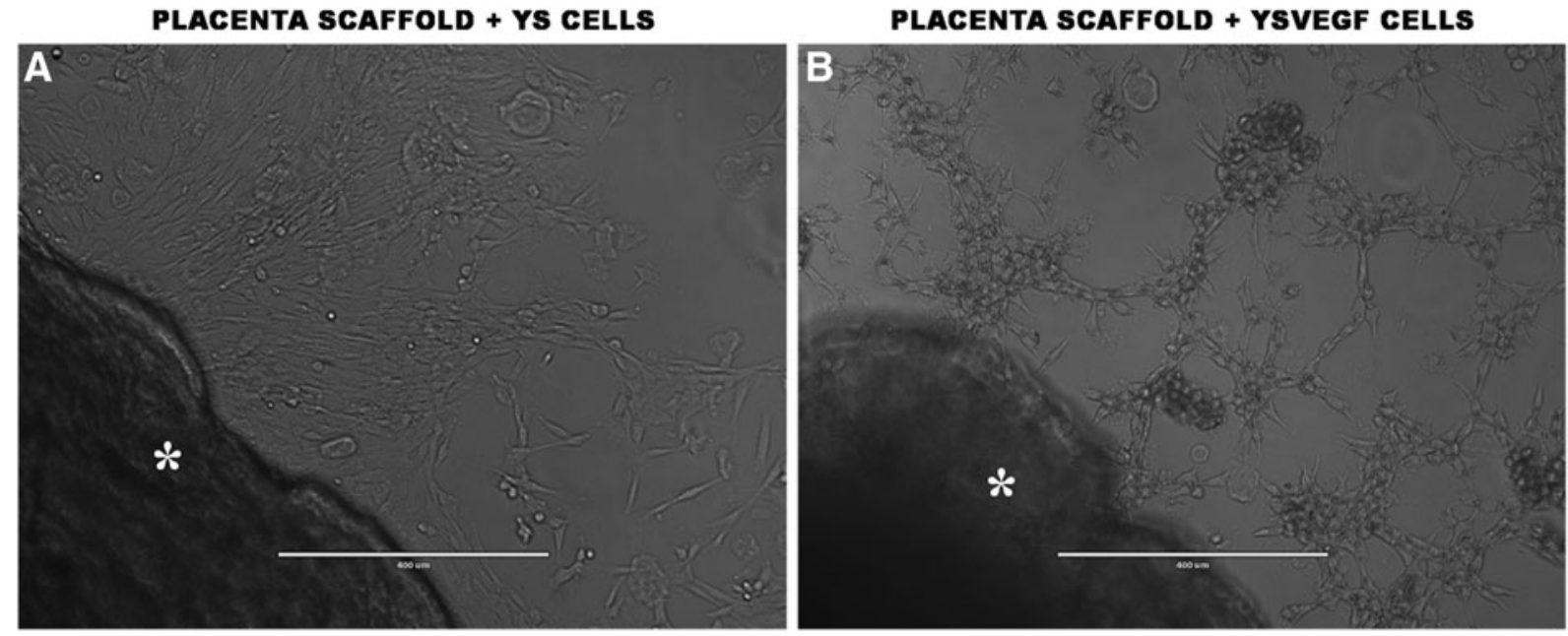

FIG. 1. Process of placenta scaffold recellularization. In (A), canine YS cells on the nonadherent plate in the presence of scaffold (asterisk). Note the fibroblastoid morphology of the cells. In (B), transduced YS cells with VEGF (YSVEGF) in the presence of scaffold (asterisk), there is a marked change in cellular morphology, with formation of small structured colonies and sproutings. VEGF, vascular endothelial growth factor; YS, yolk sac. 


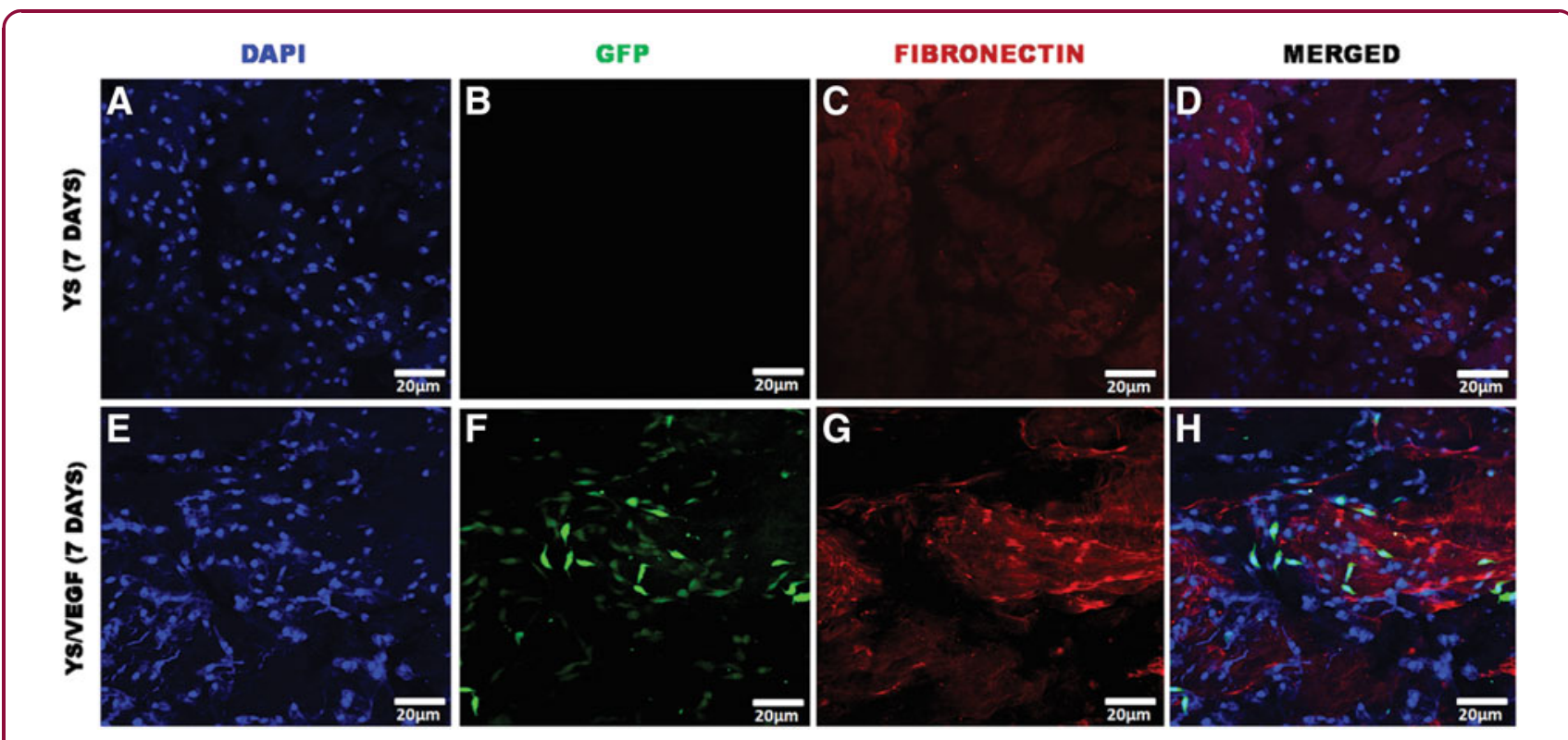

FIG. 2. Immunocytochemistry of placental canine scaffolds with YS and YSVEGF. (A-D) YS cells in the presence of scaffold, in blue (A), DAPI nuclei of YS cells, in (B), eGFP not observed, in (C), scaffold of placenta expressing fibronectin in red, in (D), YS cells in scaffold. (E-H) YSVEGF cells in scaffold of canine placenta, note in $\mathbf{( F )}$ the marked presence of YSVEGF cells expressing eGFP, in $\mathbf{( H )}$, the presence of these cells in the scaffold in red that expresses fibronectin is very clear, proving the efficient recellularization.

We used the process of agitation and immersion in sterile SDS solutions already used for a variety of tissues. These tissues include, heart valves, ${ }^{41}$ skeletal muscle, ${ }^{7,42}$ dermis $^{43}$ among others. On those studies, an amount of DNA below $50 \mathrm{ng}$ was obtained. Also, no perfusion was necessary and the ECM structure was preserved.

Supercritical carbon dioxide removes the residues from the cells as it passes through the tissues at a rate similar to the critical point. ${ }^{11}$ Our samples presented a lower concentration of residual DNA and supported the sterilization of the matrix. Most importantly, the samples were not damaged. Even though, the conditions of the critical point used were not exactly the same as those of the supercritical described, ${ }^{11}$ we believe that the process was valid to help the efficient recellularization of the scaffold.

Our method to recellularize the scaffold, using a non adherent plate, helped the migration of the cells to the scaffold. However, some cells were still adhered to the plate. To increase cell adhesion capacity, the technique used was passive sedimentation, ${ }^{44,45}$ it was chosen based on the type and porosity of the scaffold. ${ }^{46}$ Also, the relatively long period of incubation of cells in the scaffold (7 days), and finally the presence of the VEGF and the nature of the biomaterial, may have favored the success of this first recellularization trial.

The next objective will be to test other techniques, such as rotational systems, ${ }^{47-49}$ which may further enhance the success of this work. The first step has already been taken.

\section{Conclusions}

The placentas were successfully decellularized, maintaining its structural architecture. The sterilization process with UV light and critical point proved to be efficient. The YS and YSVEGF cells were adhered to the scaffold, demonstrating the ability to construct a biomaterial to be used in processes where cellular neovascularization is required.

\section{Acknowledgments}

We thank CADI-FMVZ USP for the technical support for photodocumentation of confocal microscopy and electron microscopy. Financial support: Fapesp 2014/50844-3 and 2015/50466-1. 


\section{Author Disclosure Statement}

\section{No competing financial interests exist.}

\section{References}

1. Badylak SF, Freites DO, Gilbert TW. Reprint of: extracellular matrix as a biological scaffold material: structure and function. Acta Biomater. 2015; 23:S17-S26.

2. Bader A, Schilling $T$, Teebken $\mathrm{O}$, et al. Tissue engineering of heart valveshuman endothelial cell seeding of detergent acellularized porcine valves. Eur J Cardiothorac Surg. 1998;14:279-284.

3. Kasimir MT, Rieder E, Seebacher G, et al. Comparison of different decellularization procedures of porcine heart valves. Int J Artif Organs. 2003;26: 421-427.

4. Conklin BS, Richter ER, Kreutziger KL, et al. Development and evaluation of a novel decellularized vascular xenograft. Med Eng Phys. 2002;24:173183.

5. Schmidt CE, Baier JM. Acellular vascular tissues: natural biomaterials for tissue repair and tissue engineering. Biomaterials. 2000;21:22152231.

6. MacNeil S. What role does extracellular matrix serve in skin grafting and wound healing? Burns. 1994;20:67-70.

7. Cartmell JS, Dunn MG. Effect of chemical treatments on tendon cellularity and mechanical properties. J Biomed Mater Res. 2000;49: 134-140.

8. Poornejad N, Buckmiller E, Schaumann L, et al. Re-epithelialization of whole porcine kidneys with renal epithelial cells. J Tissue Eng. 2017;8: $1-11$.

9. Scarritt ME, Pashos NV, Motherwell JM, et al. Re-endothelialization of ratlungscaffolds through passive, gravitydrivenseeding of segmentspecificpulmonaryendothelial cells. J Tissue Eng Regen Med. 2018;12: e786-ee806.

10. Stabler CT, Lecht S, Mondrinos MJ, et al. Revascularization of decellularizedlungscaffolds: principles and progress. Am J Physiol Lung Cell Mol Physiol. 2015;309:L1273-L1285.

11. Crapo PM, Gilbert TW, Badylak SF. An overview of tissue and whole organ decellularization processes. Biomaterials. 2011;32:3233-3243.

12. Hubmacher D, Apte SS. The biology of the extracellular matrix: novel insights. Curr Opin Rheumatol. 2013;25:65-70.

13. Choi JS, Kim JD, Yoon HS, et al. Full-thickness skin wound healing using human placenta-derived extracellular matrix containing bioactive molecules. Tissue Eng A. 2013;19:329-339.

14. Brigido SA, Carrington SC, Protzman NM. The use of decellularized human placenta in full-thickness wound repair and periarticular soft tissue reconstruction: an update on regenerative healing. Clin Podiat Med Surg. 2018;35:95-104.

15. Barreto RSN, Romagnolli P, Mess AM, et al. Decellularized bovine cotyledons may serve as biological scaffolds with preserved vascular arrangement. J Tissue Eng Regen Med. 2017;12:e1880-e1888.

16. Enders AC, Carter AM. The evolving placenta: convergent evolution of variations in the endotheliochorial relationship. Placenta. 2012;33:319326.

17. Miglino MA, Ambrósio $C E$, dos Santos Martins D, et al. The carnivore pregnancy: the development of the embryo and fetal membranes. Theriogenology. 2006;66:1699-1702.

18. Leiser R, Enders AC. Light- and electron-microscopic study of the near-term paraplacenta of the domestic cat. Acta Anat (Basel). 1980;106: 293-311.

19. Leiser R, Kohler T. The blood vessels of the cat girdle placenta: observations on corrosion casts, scanning electron microscopy and histological studies. Anat Embryol. 1983;170:210-216.

20. Favaron PO, Mess A, Will SE, et al. Yolk sac mesenchymal progenitor cells from new world mice (Necromys lasiurus) with multipotent differential potential. PLoS One. 2014;9:e95575.

21. Wynn RM, Amoroso EC. Placentation in the spotted hyena (Crocuta crocuta erxleben), with particular reference to the circulation. Am J Anat. 1964;115:327-361.

22. Hopper RA, Woodhouse K, Semple JL. Acellularization of human placenta with preservation of the basement membrane: a potential matrix for tissue engineering. Ann Plast Surg. 2003;51:598-602.
23. Flynn L, Semple JL, Woodhouse KA. Decellularized placental matrices for adipose tissue engineering. J Biomed Mater Res A. 2006;79: 359-369.

24. Kakabadze A, Kakabadze Z. Prospect of using decellularized human placenta and cow placentome for creation of new organs: targeting the liver (part I: anatomic study). Transplant Proc. 2015;47:1222-1227.

25. Hong JW, Lee WJ, Hahn SB, et al. The effect of human placenta extract in a wound healing model. Ann Plast Surg. 2010;65:96-100.

26. Kim J, Kim T, Park S, et al. Protective effects of human placenta extract on cartilage degradation in experimental osteoarthritis. Biol Pharm Bull. 2010;33:1004-1010.

27. Jung J, Lee $H J$, Lee JM, et al. Placenta extract promote liver regeneration in CCl4-injured liver rat model. Int Immunopharmacol. 2011;11: 976-984.

28. Kim YS, Park JJ, Sakoda Y, et al. Preventive and therapeutic potential of placental extract in contact hypersensitivity. Int Immunopharmacol. 2010; 10:1177-1184.

29. Francis MP, Breathwaite $E$, Bulysheva $A A$, et al. Human placenta hydrogel reduces scarring in a rat model of cardiac ischemia and enhances cardiomyocyte and stem cell cultures. Acta Biomater. 2017;1:92-104.

30. Fratini $P$, Carreira AC, Alcântara D, et al. Endothelial differentiation of canine yolk sac cells transduced with VEGF. Res Vet Sci. 2016;104: 71-76.

31. Leonel LCPC, Miranda CMFC, Coelho TM, et al. Decellularization of placentas: establishing a protocol. Braz J Med Biol Res. 2017;51:e6382.

32. Wijelath ES, Rahman S, Murray J, et al. Fibronectin promotes VEGFinduced CD34 cell differentiation into endothelial cells. J Vasc Surg. 2004; 39:655-660.

33. Garcia LF, Mataveli FD, Mader AMAA, et al. Cells involved in extracellular matrix remodeling after acute myocardial infarction. Einstein (Sao Paulo). 2015;13:89-95.

34. Wenceslau CV, Miglino MA, Martins DS, et al. Mesenchymal progenitor cells from canine fetal tissues: yolk sac, liver, and bone marrow. Tissue Eng Part A. 2011;17:2165-2176.

35. Auerbach R, Huang H, Lu L. Hematopoietic stem cells in the mouse embryonic yolk sac. Stem Cells. 1996;14:269-280.

36. Bonvillain RW, Scarritt ME, Pashos NC, et al. Nonhuman primate lung decellularization and recellularization using a specialized large-organ bioreactor. J Vis Exp JoVE. 2013;82:50825.

37. Kasukonis BM, Kim JT, Washington TA, et al. Development of an infusion bioreactor for the accelerated preparation of decellularized skeletalmuscle scaffolds. Biotechnol Prog. 2016;32:745-755.

38. Zhou P, Huang Y, Guo Y, et al. Decellularization and recellularization of rat livers with hepatocytes and endothelial progenitor cells. Artif Organs. 2015;40:25-38.

39. Yokomuro $\mathrm{H}$, Shiono $\mathrm{N}$, Watanabe $\mathrm{Y}$, et al. Optimal culture conditions for constructing durable biografts for repairing the impaired heartdynamic cell culture with pre-seeding. Ann Thorac Cardiovasc Surg. 2011 ; 17:481-486.

40. Teixeira GQ, Barrias CC, Lourenço AH, et al. A multicompartment holder forspinnerflasks improves expansion and osteogenic differentiation of mesenchymal stemcellsin three-dimensional scaffolds. Tissue Eng Part C Methods. 2014;20:984-993.

41. Tudorache I, Cebotari S, Sturz G, et al. Tissue engineering of heart valves: biomechanical and morphological properties of decellularized heart valves. J Heart Valve Dis. 2007;16:567-573.

42. Woods T, Gratzer PF. Effectiveness of three extraction techniques in the development of a decellularized bone-anterior cruciate ligament-bone graft. Biomaterials. 2005;26:7339-7349.

43. Reing JE, Brown BN, Daly KA, et al. The effects of processing methods upon mechanical and biologic properties of porcine dermal extracellular matrix scaffolds. Biomaterials. 2010;31:8626-8633.

44. Roh JD, Nelson GN, Udelsman BV, et al. Centrifugal seeding increases seeding efficiency and cellular distribution of bone marrow stromal cells in porous biodegradable scaffolds. Tissue Eng. 2007;13:2743-2749.

45. Roh JD, Brennan MP, Lopez-Soler Rl, et al. Construction of an autologous tissueengineered venous conduit from bone marrow-derived vascular cells: optimization of cell harvest and seeding techniques. J Pediatr Surg. 2007;42:198.

46. Ma PX. Biomimetic materials for tissue engineering. Adv Drug Deliv Rev. 2008;60:184-198. 
47. Roh JD, Nelson GN, Brennan MP, et al. Small-diameter biodegradable scaffolds for functional vascular tissue engineering in the mouse model. Biomaterials. 2008;29:1454-1463.

48. Nieponice A, Soletti L, Guan J, et al. Development of a tissue engineered vascular graft combining a biodegradable scaffold, muscle-derived stem cells and a rotational vacuum seeding technique. Biomaterials. 2008;29: 825-833.

49. Callanan, A, Davis NF, McGloughlin TM, et al. The effects of stent interaction on porcine urinary bladder matrix employed as stent-graft materials. J Biomech. 2014;47:1885-1893.

Cite this article as: Fratini P, Rigoglio NN, Matias GSS, Carreira ACO, Rici REG, Miglino MA (2018) Canine placenta recellularized using yolk sac cells with vascular endothelial growth factor, BioResearch Open Access 7:1, 101-106, DOI: 10.1089/biores.2018.0014.

$\begin{aligned} & \text { Abbreviations Used } \\ & \mathrm{ECM}=\text { extracellular matrix } \\ & \mathrm{PBS}=\text { phosphate-buffered saline } \\ & \mathrm{SDS}=\text { sodium dodecyl sulfate } \\ & \mathrm{SEM}=\text { scanning electron microscopy } \\ & \mathrm{UV}=\text { ultraviolet } \\ & \mathrm{VEGF}=\text { vascular endothelial growth factor } \\ & \mathrm{YS}=\text { yolk sac } \\ & \mathrm{YSC}=\text { yolk sac cell }\end{aligned}$

\section{Publish in BioResearch Open Access}

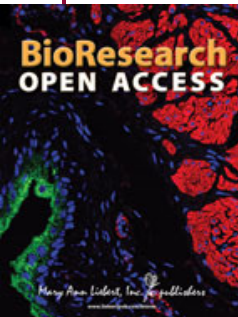

- Broad coverage of biomedical research - Immediate, unrestricted online access - Rigorous peer review - Compliance with open access mandates - Authors retain copyright

- Highly indexed

- Targeted email marketing

liebertpub.com/biores 